\title{
Legal Pluralism, Sharia Courts, AND CONSTITUTIONAL ISSUES IN ETHIOPIA *
}

\begin{abstract}
State laws employ different approaches in addressing the effect of pluralistic normative ordering in a multicultural setting. A legal regime may resort to the uniform application of state laws and reject religious and customary norms, or may recognize and allow the application of the norms and practices of identity groups as long as they are in conformity with constitutional and human rights standards. Another option is to adopt a hands-off approach whereby the norms and practices of cultural and/or religious groups are permitted to operate and are not necessarily required to meet constitutional and human rights standards. Against the backdrop of the notion of legal pluralism adopted by the FDRE Constitution, this article examines whether final decisions rendered by sharia courts in Ethiopia are required to meet constitutional standards (such as the supremacy clause, gender equality and non-discrimination). Based on the analysis of the relevant provisions of the law and literature, it is argued that decisions of sharia courts (whose jurisdiction is not compulsory, but based on the consent of litigating parties) seem to be exempted from constitutional standards even where they may be in conflict with state laws.
\end{abstract}

\section{Key words:}

Legal pluralism, sharia courts, constitutional standards, a hand-off approach, Ethiopia.

\section{Introduction}

The 1995 Federal Democratic Republic of Ethiopia (FDRE) Constitution recognizes the ethno-linguistic and religious diversity in the country. It does so, inter alia, by giving recognition to the settlement of disputes by customary and

* The article is a substantially revised version of my paper titled "Legal Pluralism vs Human Rights Issues: Sharia Courts and Human Rights Concerns in the Light of the Federal Constitution of Ethiopia", which was presented at the Seminar "The Contribution of Non-western Law to the Development of International Human Rights Law', held on 13- 14 September 2010, Brussels, Belgium. I would like to extend my thanks to Ato Elias Nour for his comments. I also would like to thank the two anonymous reviewers and an editor of the Journal who anonymously gave comments on the article.

- PhD Candidate, Human Rights Centre, Public Law Department, Faculty of Law, Ghent University, Belgium (Academic staff member, Institute of Federalism and Legal Studies, ECSC, Addis Ababa, Ethiopia). E-mail:

$<$ mohammed.mohammedabdo@UGent.be >; <mohammedza@yahoo.com> 
religious systems on matters affecting the personal status of individuals. The plurality of sources of normative ordering sanctioned by the Constitution opens room for the potential discord between non-state (i.e. customary and religious) laws and state laws (including the Constitution and international human rights treaties ratified by Ethiopia). A case in point relates to matters that fall within the jurisdiction of sharia courts. Such cases are to be resolved by Islamic law, which has normative and conceptual differences with state laws regarding the rights of women in general and their treatment in, among others, divorce, inheritance, and sharing of estate upon divorce. Decisions rendered by sharia courts using Islamic law could conflict, in general, with human rights norms, and can also, in particular, be inconsistent with rules on gender equality and other rules espoused by the Constitution.

This article examines mechanisms, if any, adopted by the FDRE Constitution to manage the potential clash of state laws with Islamic law and the decisions of sharia courts. It also examines whether final judgments pronounced by sharia courts are required to be compatible with constitutional standards (such as the supremacy clause and human rights provisions). As a prelude to this discussion, the article highlights the background of Islam in Ethiopia. It further discusses a brief history of the sharia courts in Ethiopia, the jurisdiction of sharia courts their structure and administration, and their place in the legal system. Moreover, two cases decided by sharia courts are reviewed with a view to shedding some light on the exercise of their jurisdiction and on their relationship with courts of law and the House of Federation (HoF) which is empowered to interpret the Constitution.

Although sharia courts are set up both at the federal and regional levels and in the units of the Ethiopian federation, the focus here is on the Federal Sharia Courts. The discussion on the issues raised is based on the analysis of the relevant provisions of the FDRE Constitution and laws related to the jurisdiction of sharia courts. These laws include the Proclamation to Consolidate Federal Courts of Sharia (Proclamation No. 188/1999) which is alternatively referred to as the 1999 Sharia Courts Proclamation in this article, the Civil Code, the Federal Courts Establishment Proclamation, and the laws relating to the power of the House of Federation. This is further informed by the relevant literature referred to in this article.

I argue in favour of a hands-off approach which enables final substantive decisions on matters affecting personal status to fall within the purview of sharia courts by placing them outside state laws. To put it differently, state laws should not regulate final decisions of sharia courts, and in effect, final decisions rendered by sharia courts should not be expected to meet standards of state laws as long as the procedural requirements to institute a case before sharia courts 
(which require the consent of the litigating parties to be adjudicated in a sharia court) are fulfilled.

\section{Background of Islam in Ethiopia}

Islam arrived early in Ethiopia soon after the advent of the message of Prophet Muhammad. Ethiopia is the first country that accepted Islam after Arabia and this happened following the taking refuge in Ethiopia of some of the followers of the Prophet owing to the persecution they suffered at the hands of the then powerful tribe of Mecca, Qureysh, to which the Prophet belonged. The Ethiopian king offered kind treatment and is eventually believed to have been converted to Islam, after considering the message they were persecuted for. As a result of the hospitality offered to the followers who sought safe haven and protection in the country, the Prophet ordered Muslims in general and his followers to respect and protect Ethiopians and not to engage in fighting with Ethiopians except in self-defense. This is found in the statement of the Prophet: 'leave the Ethiopians alone as long as they leave you alone', and this edict is well-known by Muslims throughout the world and Ethiopia.

During the following centuries, a limited immigration mainly from the Arab territories increased the number of Muslims in coastal areas around Ethiopia, ${ }^{1}$ in the present day Somalia and Eritrea. This enabled Islam to penetrate into these areas peacefully and Islamic norms took root gradually. The presence of Islam in the area created discontent in the dominant Christian kingdoms in Ethiopia, which considered Islam a threat. A significant conflict occurred in the $16^{\text {th }}$ century during the campaign led by the Muslim leader Ahmed Ibn Ibrahim, commonly called Ahmed Gragn, who was from the currently eastern part of the country. His aspiration was to weed out Christianity, end the leadership of kings who claim to have blood ties to King Solomon, and replace it with Islamic traditions. ${ }^{2}$ Ahmed Gragn's campaign dethroned the Christian regime and established his own rule, under the banner of Islam, in the central part of the country for about 15 years and Ethiopia nearly became a Muslim state. ${ }^{3}$

\footnotetext{
${ }^{1}$ Hussein Ahmed (2000), Islam in Nineteenth Century Wallo, Ethiopia, Revival, Reform and Reaction, Brill, Pp. 30-35; see also Horn of Africa: The Region and Its History $<$ http://www.law.emory.edu/ifl/region/hornofafrica.html $>$ (Accessed on 25 March 2011).

2 Jon Abbink (1998), "An Historical-Anthropological Approach to Islam in Ethiopia: Issues of Identity and Politics", Journal of African Cultural Studies, Volume II, No. 2, p. 114.

3 John Miles (2004), Customary and Islamic Law and Its Development in Africa, Legal Brief Africa, African Development Bank, p. 136; See also Jan Abbinik (1999), "Ethiopian Islam and the Challenge of Diversity" ISIM Newsletter, Vol. 4, p. 24. The
} 
One notable attempt by Christian rulers to forcefully convert Muslims against their will was made by Emperor Yohannes IV in the $19^{\text {th }}$ Century, who persecuted those Muslims who opposed his doctrine of forcing Muslims to embrace Christianity. ${ }^{4}$ His aim was to outlaw the practice of Islam and foster national unity through mass conversion of Muslims to Christianity. ${ }^{5}$ The whole exercise was part of the grand 'national integration' scheme designed, ever since the emergence of the imperial state, for the purpose of putting in place an overarching 'one national identity' defining Ethiopian citizenship.

Following series of campaigns of expansion of territory, the current frontiers of Ethiopia took shape under Emperor Menelik II. There has been no significant clash between Muslims and Christians thereafter and the two religions have pursued peaceful co-existence.

The emergence of the federal form of government in the 1990s has paved the way for express recognition of religious courts to deal with some personal matters. Accordingly, the FDRE Constitution has allowed a favourable legal framework for the operation of sharia courts. This gives rise to some questions regarding their jurisdiction and operation, and their relationship with organs such as courts and the House of Federation, an organ vested with the task of authoritative interpretation of the Constitution.

\section{Sharia Courts in Ethiopia: A Brief Historical Account}

Sharia courts have existed de facto since Islam was embraced in the country. ${ }^{6}$ They acquired official state recognition after the Proclamation for the Establishment of Kadis Courts was enacted in 1942. ${ }^{7}$ The Proclamation defined the jurisdiction of sharia courts which are essentially the same with the present jurisdiction of the courts. It provided that the Government would appoint judges serving in these courts. This proclamation was repealed in 1944 by the Khadis and Naiba Councils Proclamation, ${ }^{8}$ which established a three tier court structure. ${ }^{9}$

fighting led by Ahmed Gran took place between 1529 - 1543. The fighting went on after his death in 1543 under the leadership of his successor.

${ }^{4}$ Bahiru Zewde (2001), A Modern History of Ethiopia: 1885-1991, $2^{\text {nd }}$ eds., Addis Ababa University Press, p. 48.

${ }^{5}$ Abbink, supra note 2, p. 115.

${ }^{6}$ J. Spencer Trimingham (1965), Islam in Ethiopia, (London: Frank Cass \& Co.) p. 15.

${ }^{7}$ The Kadis Court Proclamation No. 2/1942. This Proclamation set up a two-tiered court structure- the Kadis Court that would serve as a court of first instance, and the Sharia Court, which would act as an appellate court.

${ }^{8}$ The Khadis and Naiba Councils Proclamation, Proclamation No. 62/1944.

${ }^{9}$ Ibid. 
The enactment of the 1960 Civil Code, which calls for the uniform application of its rules regarding all civil matters, put the legal status of the sharia courts in difficulty. Article 3347 of the Code provides that "[u]nless otherwise expressly provided, all rules whether written or customary previously in force concerning matters provided for in this Code shall be replaced by this Code and hereby repealed." Some contend that this provision repeals the law establishing sharia courts. ${ }^{10}$ According this interpretation, the repeal of the sharia courts by Article 3347 is implied as the Civil Code contains no exceptional provisions relating to personal laws of Muslims and sharia courts. Since the Civil Code repealed all previously enforced written and customary rules, there is no exception made to any group, and in effect, the argument is that sharia courts are no longer recognized and their jurisdiction to apply Islamic law is annulled. ${ }^{11}$

A contrary argument is that since such courts were in existence and applying Islamic law to some extent, the Civil Code, which makes no reference to the courts, did not intend to revoke their jurisdiction. ${ }^{12}$ In the midst of this debate regarding the effect of Article 3347 of the Civil Code on sharia courts, the Minister of Justice issued a circular which allowed the sharia courts to continue to exercise their jurisdiction. ${ }^{13}$

The ambiguity regarding the status of the Sharia Courts under the 1960 Civil Code appears to have been deliberate. Ethiopia at that time was struggling to come to grips with the question of allowing a distinct law for Muslims. ${ }^{14}$ One can, therefore, realize the dilemma created by the desire for uniform law under

${ }^{10}$ Zaki Mustapha (1973), "The Substantive Law to be Applied by Muslim Courts in Ethiopia", Journal of Ethiopian Law, Vol. 9, No. 1, p. 140; James C. N. Paul and Christopher Clapham (1971), Ethiopian Constitutional Development: A Source Book Volume II (Haile Sellassie I University), p. 849, citing Robert A. Sedler (1967), “ The Development of Legal Systems: The Ethiopian Experience", Iowa Law Review, Vol. 53. see also Ibrahim Idris (1999), "Sharia Courts in Eight secular African and Asian Countries", a Paper presented at the Conference Reviewing the Draft Proclamation to Consolidate Sharia Courts, (Addis Ababa, Ethiopia), p. 14.

${ }^{11}$ Ibid. In the family law section of the Code, the expert drafter of the Code, a French Jurist, Rene David, had incorporated, addition to Article 3347, provisions governing Muslim community. However, during the deliberations in parliament on the draft Code, the proposed provisions relating to Muslims were set aside and Article 3347 was retained. See Zaki Mustapha, op. cit., p. 142.

${ }^{12}$ Ibid.

${ }^{13}$ Ibid. The issuance of the circular came following the request of the then President of Sharia courts for the continuation of operation of the courts after the entry into force of the Civil Code that put the status of the courts in doubt.

${ }^{14}$ Paul and Clapham, supra note 10, p. 849. 
the Civil Code (legal universalism), and the competing need to recognize a religious law for the Muslim communities. Ultimately, the action of the Minster of Justice gave regard to the interest of Muslims and allowed the sharia courts to exercise their jurisdiction.

The FDRE Constitution of 1995 recognized the sharia courts and it is the first Ethiopian Constitution to give such recognition to religious and customary laws in dispute settlement. Questions that emanate from the constitutional recognition of the courts are the subject of treatment in the last section of this article.

\section{The Role of Sharia Courts in a Predominantly Christian Country}

Although Ethiopia is the first country that embraced Islam after the Arabian peninsula, it is long considered as an island of Christianity. Christianity had the status of state religion up to the mid-1970s and the Ethiopian Orthodox Church had a significant leverage on the emperors of the country because they were required to have the consecration of the Church to secure legitimacy to rule the country. The Church was also entitled to the ownership of a third of the land in Ethiopia, and it had a significant influence in the political and legal traditions of the country. ${ }^{15}$

There has been tolerance between Muslims and Christians in the country. Yet, the state considered itself to be the steward of the Orthodox Church and relegated Muslims to a second-class status. ${ }^{16}$ Prior to the 1970 s, Muslims especially in the Northern part, were excluded from the customary land-holding system. ${ }^{17}$ Moreover, they could not hold senior political positions, and were barely represented in various posts commensurate with their number. ${ }^{18}$ Muslims were also disadvantaged in the realms of education, employment, and other realms. ${ }^{19}$ Thus, they were mostly engaged in trade and commerce. ${ }^{20}$

${ }^{15}$ Christopher Clapham (1969), Haile-Selassie's Government, Praeger Publishers, p. 82; see also Abbinik, supra note 3.

${ }^{16}$ Bahru Zewde, supra note 4, p. 7; see also Abbink, supra note 2, p. 114.

${ }^{17}$ Ibid. See also Abdalla Bujra (2002), 'Islam in Eastern Africa: Historical Legacy and Contemporary Challenges', p. 4.

${ }^{18}$ Abbink, supra note 3, p. 24, see also Clapham, supra note 15, p. 83. Muslims were not allowed to assume any positions in the army, police and security apparatus before 1974. See Bujra, supra note 17, p. 4.

${ }^{19}$ Clapham, supra note $15, \mathrm{Pp}$. 83-84. The reason for what appears to constitute a systemic discrimination against Muslims has to do with the nature of Muslims in the country. Islam has emerged, in the words of Abbink, in the shadow of Christianity and has always been a secondary and inferior religion in the country. See Abbink, supra note 2, p. 113. 
One wonders why the sharia courts received state recognition, tacitly for a long time before the 1940s, and expressly after 1942, under these conditions. At least three factors can be stated in relation with the de facto operation of sharia courts before the 1940s. The first factor may be ascribed to the prolonged periods of peaceful co-existence and the culture of tolerance between Muslims and Christians, which entitled Muslims to practice their religion freely. ${ }^{21}$ The second reason that explains their tacit recognition is that historically, the settlement of personal and family matters have been based on each community's religions and customary norms. ${ }^{22}$ Moreover, the particular geographical location of most Muslims who were predominantly concentrated in the peripheries of the country made it difficult for state laws to penetrate into these areas.

One could raise other factors for the state recognition of Sharia Courts in the early 1940s. The first may be attributable to the criticism levelled against the Ethiopian government, during the reign of Emperor Haile Sellassie I, by states such as Egypt for the treatment Muslims in the manner discussed above. ${ }^{23}$ The de jure recognition of the courts may, to a certain extent, be an act of appeasing foreign criticism and showing that Muslims had the right to be governed by their own religious law and that they enjoy freedom of religion.

The second reason may have to do with the timing of the request of Muslims to set up the sharia courts. The request of Muslims came soon after the end of the brief occupation of Ethiopia by Italy from 1936 to 1941. To achieve its colonial aspiration and to attract support from one group against the other, Italy devised different strategies including the administrative division of the country along ethnic, linguistic and religious lines. With this end in view, the Italian occupation systematically favoured the Muslims at the expense of the Christians. They recognized freedom of religion of Muslims, invigorated Islamic education, and introduced Arabic in schools. ${ }^{24}$ Muslims were encouraged to make use of the sharia courts as a ploy of getting their support and thereby creating division in the country along religious lines. ${ }^{25}$ This explains the proliferation of sharia courts during the occupation. ${ }^{26}$

${ }^{20}$ Bujra, supra note 17 , p. 4 . In fact, business activities in which Muslims have been engaged were despised by Christians and the ruling elite in the past and this also explains why Muslims were dominant in commerce and trade.

${ }^{21}$ Ibid; see also Paul and Clapham, supra note 10, p. 849.

${ }^{22}$ Miles, supra note 3, p. 137; see also Paul and Clapham, supra note 10, p. 849. Christians had such courts that deal with family issues but their jurisdiction was abolished in 1940s.

${ }^{23}$ Miles, supra note 3, p. 137.

${ }^{24}$ Abbink, supra note 2, p. 117.

${ }^{25}$ Italy had encouraged the use of local languages to create division along language lines as well. Accordingly, the Oromo language was made, for the first time, a media 
At the end of the occupation, the Emperor accepted the request for the recognition of sharia courts possibly in order to prevent the threat of division along religious lines. ${ }^{27}$ This may indicate why the Emperor accepted the request of Muslims to set up sharia courts in 1942.

The Government's move in recognizing sharia courts and their jurisdiction in personal and family affairs are intrinsically tied with the preservation of one's culture and identity. On the contrary, the uniform application of the Civil Code irrespective or religion would have been strongly resisted by Muslims and could have led to social unrest. ${ }^{28}$

\section{Sharia Courts under Ethiopian law: Contextualizing the Operation of Sharia Courts}

A brief overview of the relevant human rights norms under the FDRE Constitution and a brief outline about the legal system of Ethiopia are necessary in order to shed light on the structure within which the sharia courts operate. Moreover, they can enable us to look into the relationship of sharia courts with the regular courts and with the organ in charge of the interpretation of the Constitution itself, i.e., the House of Federation.

The FDRE Constitution of 1995 has adopted a federal system and it has established a secular and parliamentary system. The Constitution gives due regard to fundamental rights and freedoms, and human rights are among the fundamental principles of the Constitution. It is to be noted that nearly a third of the provisions of the Constitution deal with human rights and an entire chapter (i.e., Chapter Three) is devoted to human rights. This is not surprising given the fact that it was adopted following the demise of the 17-year military dictatorship

language in the history of the country during the period of the brief occupation. The use of the language was banned after Italy was defeated and soon after the Emperor returned from exile in UK. The Emperor thought the use of local language would create a rift in the country and undermine the unity of the state.

${ }^{26}$ Mohammed Siraj (1999), "The Constitution of the FDRE Constitution and the Application of Sharia Law", a Paper presented at the Conference Reviewing the Draft Proclamation to Consolidate Sharia Courts, (Addis Ababa, Ethiopia), p. 8.

${ }^{27}$ This may be discerned from the famous speech of the Emperor emphasizing that "The country is common to all while religion is personal", which was delivered to Muslim leaders and elders at the occasion of the day marking the end of the Muslim month of fasting. See Mohammed Siraj, supra note 26, p. 8. Following the speech, Muslims at the gathering asked the Emperor himself for the official setting up of sharia courts.

${ }^{28}$ Paul ad Clapham, supra note 10, p. 849. 
in 1991 and at the time when the wave of democratization started to spread after the disintegration of the former USSR, marking the end of the Cold War. ${ }^{29}$

The Constitution embodies a Bill of Rights under Chapter Three, which divides fundamental rights and freedoms into human rights and democratic rights. ${ }^{30}$ The civil and political rights stipulated under Articles 15-28 are more or less in line with the UN Covenant on Civil and Political Rights, while Articles 29-44 provide for democratic rights. Social and economic rights are embodied in Article 41 of the Constitution and other provisions which are relevant to these rights.

The Constitution seems to have given a strong adherence to international treaties with respect to their domestic application. Article 9(4) provides that international treaties ratified by Ethiopia are the integral part of the law of the land. Furthermore, Article 13(2) of the Constitution requires the provisions on human rights to be construed in conformity "to the principles of the Universal Declaration of Human Rights, International Covenants on Human Rights and international instruments adopted by Ethiopia." This, inter alia, requires the constitutional provisions on equality and non-discrimination to be interpreted in conformity with the principles of international human rights instruments to which Ethiopia is a party.

Article 25 of the Constitution guarantees equality before the law and equal protection of the law. Accordingly, it states that all persons are equal before the law and are entitled without discrimination to equal protection of the law. The provision stipulates that "the law shall guarantee to all persons equal and effective protection without discrimination on grounds of race, nation, nationality or other social origin, colour, sex, language, religion, political or other opinion, property, birth or other status." To ensure that other laws are compatible with the constitutional provisions on human rights and equality, some laws, including the 1960 Civil Code provisions on family law and the 1957 Penal Code were revised in 2000 and 2004 respectively.

Article 35 of the Constitution, titled 'Rights of Women' reiterates the right to equality of men and women in the enjoyment of rights and the protection provided for by the Constitution. The provision also states the equal rights of women with men in marriage, employment, and property ownership and administration. Moreover, Article 35(3) prohibits laws, customs, practices that oppress or cause harm to women and it champions affirmative action for women

${ }^{29}$ Mohammed Abdo (2011), "The Status and Enforcement of Social and Economic Rights under the FDRE Constitution", Journal of Ethiopian Law, Vol. 24.

${ }^{30}$ Such distinction does not exist under international human rights instruments and is not the case with the conventional classification of human rights either. 
to rectify the inequality between men and women in the political, social and economic realms. The Constitution thus provides a strong protection to the rights of women and forbids discrimination against them.

The Constitution sets up a parallel court structure at federal and regional state levels. Federal Courts are competent to handle federal matters and state courts entertain state matters. Details of the jurisdiction of the federal courts, their specific structure and relationships, and administration are set forth in the Federal Courts Establishment Proclamation of $1996 .{ }^{31}$ Sharia courts pursue the same structure and they have a three-tiered structure: First Instance Court, High Court and the Supreme Court. The same structure is adopted by Regional States in establishing Regional sharia courts in their respective units.

Sharia courts are found at both the Federal and State levels ${ }^{32}$, and they are not part of the regular court structure. Consequently, their decisions cannot be subject to appeal to the regular courts of law. Once a case is submitted to civil courts, it may not be transferred to sharia courts and vice versa ${ }^{33}$. They can, therefore, be treated as distinct organs with a judicial function outside the regular judiciary.

The FDRE Constitution does not grant power to courts of law in relation to the constitutional review of acts of parliament. The power to examine the constitutionality of laws enacted by parliament is vested in the House of Federation, which is equivalent to a chamber of parliament, in other countries, but is devoid of law making power. ${ }^{34}$ Thus courts of law at any level, including the Federal Supreme Court, do not have the power to proclaim laws enacted by parliament unconstitutional. In interpreting the Constitution and in examining the constitutionality of laws, the House of Federation is assisted by an organ known as the Council of Constitutional Inquiry. The Council is empowered to advise the House of Federation (HoF), investigate complaints on cases that involve constitutional issues and offer recommendation to $\mathrm{HoF}$ for final decision

${ }^{31}$ Federal Courts Establishment Proclamation, Proclamation No. 25/ 1996 (hereinafter referred to as the Federal Courts Proclamation).

${ }^{32}$ It is only one region, Gambella Regional State that has not yet set up Sharia courts.

${ }^{33}$ See Article 5(4) of A Proclamation to Consolidate Federal Courts of Sharia, Proclamation No. 188/1999.

34 The granting of power to interpret the Constitution to the House of Federation is perhaps a unique arrangement introduced by Ethiopia as constitutional interpretation elsewhere is vested in the highest court of the land or a special constitutional court set up for such purpose. Aside from the interpretation of the Constitution, the House is entrusted with powers, among others, to decide on the right to self-determination, to formulate scheme for allocating budget to the units of the federation, and to settle disputes between the units and foster unity among the people. 
on constitutional disputes. ${ }^{35}$ The HoF acts as a constitutional court but is distinct from a regular court structure and forms part of the legislature.

Apart from regular courts, the FDRE Constitution recognizes the establishment of bodies that have judicial and/or quasi judicial functions that are required to follow due procedures. ${ }^{36}$ This indicates that courts do not have the monopoly over judicial functions. That is why Articles 34(5) and 78(5) of the Constitution recognize the resolution of disputes by customary and religious systems so long as the parties thereof consent to the settlement of disputes by such organs. It is based on this constitutional framework that Sharia Courts that deal with some personal disputes have been established.

The recognition given to customary and religious courts to engage in dispute settlement implies that the Constitution recognizes the religious and cultural diversity in the country. This arrangement may raise some questions with regard to human rights norms, especially the equality clause, when it is applied, especially, to the rights of women. This is recently underscored by the Committee on Elimination of All form of Racial Discrimination. The Committee stated that it did not receive report on the measures taken regarding the application of religious and customary laws subject to the consent of parties but underscored that the state should take measures to ensure that the application of such laws would not lead to de facto discrimination against members of ethnic groups or against women, for instance, in family disputes. ${ }^{37}$

The application of the jurisdiction of customary and religious systems is limited to personal matters and family disputes and it is interesting to see whether they should meet the constitutional standards embodied under Article 9(1) which states that "[a]ny law, customary practice or a decision of an organ

${ }^{35}$ Article 6 of the Council of Constitutional Inquiry Proclamation, Proclamation No. 250/2001(hereinafter referred to as the Council of Constitutional Inquiry Proclamation).

${ }^{36}$ See Articles 37 and 78(4) of the Constitution. However, it expressly prohibited the establishment of special or ad hoc courts which usurp judicial power from regular courts or institutions legally empowered to exercise judicial function. The aim of this provision is clear-it is to reverse the past history where such courts were established outside the regular court structure and had caused injustices against the accused persons tried by them, who in most cases received harsh decisions that were delivered contrary to all the rules of procedural fairness. See Mohammed Abdo (2010), "Civil Procedure: Monograph 55-Ethiopia," International Encyclopaedia of Laws, Kluwer Law International, p. 8.

37 Committee on the Elimination of All Forms of Racial Discrimination (2009), "Consideration of Reports Submitted by States Parties under Article 9 of the Convention: Ethiopia", at its $75^{\text {th }}$ Session, 3-28 August 2009, CERD/C/ETH/CO/716, (7 September 2009, Geneva), p. 2-3. 
of state or a public official which contravenes this constitution shall be of no effect." This provision evokes the issue whether decisions of sharia courts should yield to the supremacy clause of the Constitution and norms of human rights. Owing to the fact that customary and religious values and rules are frequently raised as perpetuating discrimination against women, it is important to examine this question. ${ }^{38}$

\section{Structure and Administration of Sharia Courts}

As a prelude to the discussion on the structure of Sharia Courts in Ethiopia, some comparative look can be made at the structure of such courts in various countries among which we can use Kenya and Zanzibar as examples. Both the previous and the current constitutions of Kenya recognize the establishment of sharia courts. The Revised 2010 Constitution of Kenya recognizes the setting up of Khadis' Courts, the equivalent of Sharia Courts in Ethiopia, and provides for their structure and jurisdction. ${ }^{39}$ The Constitution provides that the Khadis' Courts are subordinate to the regular courts of the land. ${ }^{40}$ The Khadis' Courts have a two tiered structure, Khadis' Courts and the Chief Khadi, which serves as an appellate court. As provided in the Act which is still in force in Kenya, appeal from the decisions of Khadis' Courts can be filed to the High Court and finally to the highest court in the judicial structure, i.e., the Court of Appeal.

In Zanzibar, the Constitution and a statute recognize the establishment of Khadi Courts with a structure and jurisdiction similar with that of Kenya. The final decisions of Khadi courts in Zanzibar are subject to review by the High Court, but unlike the practice in Kenya, the Court of Appeal in Tanzania does not have jurisdiction to see cases decided by such courts. ${ }^{41}$ The courts are thus at liberty to interpret the substantive Islamic law based on the nature of cases appearing before them. However, if there is inconsistency between Islamic law and the general law of the land, an express provision of the latter law would prevail over the former as far as that particular inconsistency is concerned. ${ }^{42}$

${ }^{38}$ In addition to Committee under the CERD, the CEDAW Committee also raised this issue during discussion on the reports submitted to the Committee by Ethiopia, see Committee on the Elimination of Discrimination against Women (2004), "Consideration of Reports Submitted by States Parties under Article 18 of the Convention: Combined fourth and fifth periodic report of Ethiopia", $646^{\text {th }}$ meeting, 27 January 2004, CEDAW/C/SR.646, (New York), p. 6.

${ }^{39}$ See Article 169 and 170 of the new Kenyan Constitution of 2010.

${ }^{40}$ Ibid, Article 169.

${ }^{41}$ See Article 99(2) of the Constitution of Zanzibar of 1984.

${ }^{42}$ H. Majamba (2007), "Possibility and Rationale of establishing Khadi Courts in Tanzania Mainland", Paper Presented at the Research and Education for Democracy in Tanzania Workshop (University of Dar Es Salaam), p. 12. 
This means that the substantive Islamic law used by the Khadi Courts to dispose of cases should be compatible with express rules of the general law of the land.

The structure of the sharia courts in Ethiopia is similar to that of the Federal and Regional State courts. It is of a three-tiered structure: the First Instance Court of Sharia, the High Court of Sharia, and Supreme Court of Sharia, each with its own Kadis (judges) and has a registrar and other personnel to run the activities of the courts. The sharia courts are accountable to the Judicial Administration Council, an organ in charge of, among others, selecting judges and dealing with disciplinary matters of the judges of Ethiopia's regular courts.

Members of the Judicial Administrative Council are established, staffed and funded by the government. They do not form part of the regular courts of the land, i.e., they are distinct from the regular court structure and are not subordinate to the regular courts. Unlike the legal regimes in Kenya and Zanzibar, there is no possibility of appeal from the decisions of the sharia courts in Ethiopia to the regular court structure. Article 5(4) of the Federal Courts of Sharia Consolidation Proclamation No.188/1999 expressly provides that "[u]nder no circumstance shall a case brought before a court of Sharia the jurisdiction of which has been consented to, be transferred to a regular court; nor shall a case before a regular court be transferred to a court of Sharia". ${ }^{43}$ This rule seems to have been designed with a view to delineating a clear line between the two different laws in the anticipation of the inevitable clash between the substantive law applied by (and the decisions of) sharia courts and formal state laws. The intention of Article 5(4), therefore, seems to enable the sharia courts to operate distinct from the regular courts.

In considering matters that fall within their competence, sharia courts are required to apply substantive Islamic law. However, they are obliged to follow the rules governing civil proceedings used by ordinary civil courts. The substantive sharia law is, therefore, to be applied through the implementation of the Civil Procedure Code that governs the proceedings before ordinary civil courts. For instance, hearing proceedings, production and administration of

${ }^{43}$ It is not clear whether the word 'transfer' precludes a possibility of review by civil court of decisions of sharia courts, especially review by cassation exercised by the Federal Supreme Court. The word 'transfer' does not seem to have been intended to be used in the sense of the Civil Procedure Code whereby a case filed to one court may be transferred to another court if the hearing of the case is found to be inconvenient for the defendant owing to the location of the forum or if it is believed that there will be miscarriage of justice; See Article 31 of the Civil Procedure Code. Thus one could construe and employ the word 'transfer' in its wider meaning different from the ordinary usage of the term to merely refer to the transfer of a case from one court to another. 
evidence, disposing cases and the execution of judgments of sharia courts are regulated by the Civil Procedure Code. The anomaly in the application of rules on civil procedures of ordinary courts to sharia courts lies in the fact that these rules of procedure may conflict with the substantive rules applied in sharia courts, as is to be briefly highlighted in the next section.

\section{Jurisdiction of Sharia Courts}

The constitutions and/or laws of many countries with a sizeable number of Muslim population recognize the need for the establishment of Muslim courts. ${ }^{44}$ In full-blown theocracies such as Saudi Arabia, Islamic law applies across the board, and Islamic courts are the courts of the land and have general jurisdiction on all matters. The courts have limited jurisdiction in secular states (with a significant number of Muslims) and their jurisdiction is mostly confined to matters affecting personal status that involve Muslims.

For instance, in Kenya, the jurisdiction of Khadis' Courts is over matters relating to personal status, marriage, divorce, succession or inheritance in cases in which the parties thereof are Muslims. ${ }^{45}$ In Nigeria, the jurisdiction of sharia courts is also regarding matters affecting personal status and family issues. They have jurisdiction over any question relating to the validity or dissolution of marriage involving Muslims or whether the marriage is concluded according to Islamic Law. Moreover, sharia courts in Nigeria assume jurisdiction with regard to family relationship or the guardianship of an infant, and regarding any question of Islamic personal law such as gift, will or inheritance where the endower, donor, testator or a deceased is a Muslim. ${ }^{46}$

In Ethiopia, the jurisdiction of sharia courts is drawn from the Constitution and the establishment legislation of the sharia courts. The FDRE Constitution does not directly determine the specific jurisdiction granted to sharia courts, but rather recognizes the possibility of settlement of personal disputes by customary and religious systems. It does not define the personal matters amenable to the jurisdiction of such systems. However, the Constitution provides the general areas of competence (i.e., personal matters) and the condition attached (i.e., consent of parties) to the exercise of jurisdiction by sharia courts. The specific types of cases falling within the competence of sharia courts are defined under the Federal Courts of Sharia Consolidation Proclamation No.188/1999 that was promulgated pursuant to Articles 34(5) and 78(5) of the Constitution.

\footnotetext{
${ }^{44}$ The courts could appear in different names such as Khadi Courts, Khadis' Courts, Sharia Courts, and Cadi courts.

${ }^{45}$ See for instance Article 170(5) of the 2010 Constitution of Kenya.

${ }^{46}$ See Article 262(2) and 277(2) of the 1999 Nigerian Constitution.
} 
Ever since sharia courts were set up by official state law in the 1940s, the jurisdiction of sharia courts has remained the same, and the courts are granted mandate in two types of cases, which are stated under Article 4 of Proclamation No.188/1999. ${ }^{47}$ It is in fact in the areas of family law that the influence of religious as well as customary rules are most visible and the jurisdiction conferred upon sharia courts is made in recognition of this fact. ${ }^{48}$ As is clearly indicated in the provisions that deal with the jurisdiction of sharia courts, personal and family matters are the only cases to which Islamic law applies, and thus sharia courts do not have the power to deal with other matters. This is the case with sharia courts in many states that confine the jurisdiction of the courts to matters affecting personal status of Muslims, except full-fledged theocracies, such as Saudi Arabia where their jurisdiction is wider. ${ }^{49}$

As provided under the1999 Sharia Courts Establishmen Proclamation and the FDRE Constitution, the condition attached to the exercise of jurisdiction by sharia courts is the consent of the parties. Sharia courts do not, therefore, have compulsory jurisdiction over parties on the matters that fall within their reach unless both parties demonstrate their express and unequivocal consent to the exercise of jurisdiction by the courts. ${ }^{50}$ There is no clear guideline as to when and how the consent of the parties must be expressed. ${ }^{51}$ However, one can draw the rules relating to consent from the Civil Procedure Code as the 1999 Sharia Courts Proclamation provides that the rules of procedure governing the proceedings before the sharia courts are those of the Civil Procedure Code. ${ }^{52}$

Normally, a party who files a case as a plaintiff can be presumed to have shown his/her consent to the jurisdiction of the court. However, there can be a problem in establishing the consent of the party against whom a claim is made. The 1999 Sharia Courts Proclamation provides that along with the notice to be

47 Article 4 of the 199 Sharia Courts Proclamation provides that the courts have jurisdiction on any question regarding marriage, divorce, maintenance, guardianship of minors and family relations; provided that the marriage to which the question relates was concluded, or the parties have consented to be adjudicated in accordance with Islamic law; any question regarding Wakf, gift succession of wills, provided the endower or donor is a Muslim or the deceased was a Muslim at the time of his death.

${ }^{48}$ The old and new family codes recognize the validity of marriage concluded as per religious rules and ceremonies.

49 Zaki Mustapha, supra note 10, op. cit., p. 138.

50 See Article 34(5) of the Federal constitution and Article 4(2) of the 1999 Sharia Courts Proclamation.

${ }_{51}$ Miles, supra note 3, op. cit., p. 142.

${ }^{52}$ Article 6(2) of the 1999 Sharia Courts Proclamation. A party who wishes to object to the jurisdiction of any court on the basis of want of jurisdiction can raise it as a preliminary objection under Article 244 of the Civil Procedure Code. 
served on the defendant, a form shall be attached in which the defendant declares that he/she expressly consents to the hearing of the case by sharia courts. It is possible that the defendant may not fill in the declaration but appear during the opening of the hearing of a suit and raise his/her preliminary objection orally against the exercise of jurisdiction by a sharia court. ${ }^{53}$ There is a tacit consent and a sharia court proceeds to hear a case, ex parte, if the defendant who has been duly served with the summons fails to appear at the first hearing of a suit. ${ }^{54}$ Some of the issues in connection with securing consent of parties will be reviewed in the next section.

Another condition attached to the exercise of jurisdiction by sharia courts is that the jurisdiction can only be invoked where the marriage was concluded according to Islamic law, which normally means that the parties are Muslims, or where the parties (who may even be non-Muslims) consent to get their cases handled by sharia court. ${ }^{55}$

\section{Main Issues in relation to Jurisdiction and Performance of Sharia Courts}

This section examines the performance of sharia courts on the basis of the relevant laws. Reference is also made to cases decided by sharia courts, one of which was reviewed by the Federal Supreme Court and the House of Federation. The cases highlight the relationship between sharia courts and the regular court system.

\subsection{Issues related to Securing Express Consent of both Parties}

Securing the consent of parties to the adjudication of a dispute in a sharia court is one of the debatable issues and it has led to the revision of some final decisions of the courts by the Federal Supreme Court and the House of Federation. Some cases show that the final decision rendered by the sharia courts can be reviewed by the Federal Supreme Court and the House of Federation if it is established that no express consent was secured by sharia courts before it decided on a case. One famous case in this regard is the Kedija Beshir case ${ }^{56}$ Kedija got a house following the passing away of her husband. Close relatives of her husband lodged a case to the First Instance Sharia Court

53 This is derived from Article 244 of the Civil Procedure Code, which equally apply to the proceedings before Sharia courts.

54 See Article 5(2) of the 1999 Sharia Courts Proclamation. This is in line with Article 70 of the 1965 Civil Procedure Code of Ethiopia.

55 Article 2 of the first sharia courts legislation (Proclamation No. 12/1942) limited the jurisdiction of sharia courts to Muslims only.

${ }^{56}$ Federal Supreme Court Cassation Division File No. 12400/1999. 
with a view to claiming a share from the estate. She raised an unequivocal objection to the jurisdiction of the Court. In spite of her clear objection, the Court considered the case and finally decided on the claim filed by the relatives of her husband and forced her to relinquish the house she acquired. She appealed against the decision to the High Sharia Court and Supreme Sharia Court, and both upheld the decision of the First Instance Sharia Court.

She submitted her application for the Cassation Division of the Federal Supreme Court, pursuant to Articles 80(3) of the Federal Constitution and Article 10 of the Federal Courts Establishment Proclamation. The Cassation Division decided against her by stating that there was no fundamental error of law in the decisions made by all the Sharia Courts that could lead to the review of the case.

Acting on behalf of Kedija, the Ethiopian Women Lawyers' Association brought the case to the House of Federation, the final arbiter of constitutional cases, by alleging that the adjudication of the case by the Sharia Courts against her express objection violates the Constitution. The House of Federation held the decision unconstitutional and stated its is regular courts that have compulsory jurisdiction and that sharia courts can assume jurisdiction only based on the consent of the parties pursuant to Article 34(5) of the Constitution. It also rejected the reasoning of the Sharia Court that the requirement of consent under 1999 Sharia Courts Establishment Proclamation would not apply to the case because the case was filed prior to the Proclamation's publication in the Negarit Gazzeta. ${ }^{57}$

In Hajji Kassim Mohammed and Zenit Ali's case ${ }^{58}$ marriage was concluded before a sharia court judge in the presence of two witnesses. Zenit's two brothers and her uncle filed an objection to the marriage before the First Instance Sharia Court alleging that there was no consent of her parents and relatives to the marriage. Zenit's relatives argued that under Islamic law parents and relatives must consent to the marriage. They claimed that they were never consulted and that the spouses did not invite them to attend the process before a judge. The spouses did not appear and express their consent to the jurisdiction of

${ }^{57}$ The Proclamation had not entered into force when the case was filed, but it entered into force when Kedija appeared for the first hearing of the suit. The Sharia Court held that the Proclamation would not apply to an already filed case but the House of Federation decided that what is important is securing the consent of parties indicated in the Constitution irrespective of whether or not the Proclamation had entered into force.

${ }^{58}$ Abdurahman Ali et al Vs Hajji Kassim Mohammed and Zenit Ali. See Miles, supra note 3 , at 144 . 
the First Instance Sharia Court. Nevertheless, the court decided to annul the marriage.

It appears that the court assumed jurisdiction because it considered failure of the parties to appear before it amounts to tacit acceptance of its jurisdiction. The law establishing the sharia courts provides that it can assume jurisdiction on the basis of an implied consent. Tacit consent may be inferred from the failure of the party to appear before the court so long as summons has been duly served on the defendant(s). However, the court did not investigate whether the summons has been duly served. The couple appealed to the High Sharia Court and then to the Supreme Sharia Court. Both upheld the decision of the lower court.

A problem worth noting in this regard is that sharia courts are lenient towards the interpretation of the consent of litigating parties to their jurisdiction. They do not usually ask the parties to give their express consent to the jurisdiction of the court upon their first appearance. The reason for this is probably because the judges assume that the parties have agreed, by virtue of their faith, to be governed by Islamic law; and thus they will be committed to it by their perceived prior consent. The problem is exacerbated by the behavior of the parties who do not usually express their explicit rejection of the jurisdiction of sharia courts for fear of negative perception and reaction from the Muslim community. Or they may feel that such an express objection will be considered as an affront to one's religion. In effect, they may be put under social pressure not to demonstrate opposition to the jurisdiction of sharia courts.

\subsection{Procedural Problems related to Sharia Courts Proceedings}

The application of the Civil Procedure Code to sharia courts may compromise the effective operation of the courts. Islamic law in general has a less complex procedure in the submission and administration of evidence, on the number of witnesses, examination of witnesses, and hearing of parties. The application of the Civil Procedure Code could also be in conflict with substantive Islamic law, ${ }^{59}$ which is applicable in a given case. Lack of Islamic rule of procedure seems to have led the legislator to prescribe the Civil Procedure Code for the proceedings of sharia courts. Likewise, the Khadis' Courts in Kenya are bound to follow the procedural rules of their regular courts until the Chief Justice puts in place rules regulating their procedures. ${ }^{60}$ The legislation establishing sharia courts in Ethiopia does not, however, authorize them to adopt their own rules of procedures.

59 Ibrahim Idris (2002), "Status of Federal Sharia Courts under the 199[5] FDRE Constitution", in Centre for Contemporary Islam eds., Islamic Law in Africa Project, Proceedings of Symposium (University of Cape town, South Africa).

60 Majamba, supra note 42 , at 9. 


\subsection{Lack of Codified Islamic Law and Inconsistency in Decisions}

Articles 4 and 6 of the 1999 Sharia Courts Establishment Proclamation allow sharia courts to adjudicate the expressly indicated matters in accordance with Islamic law. There is, however, absence of guiding substantive rules for the settlement of disputes submitted to sharia courts. Thus judgments are usually influenced by the particular school of thought to which a judge adheres.

In Sunni Islam, there are four schools of thought and three of them are found in Ethiopia, the predominant of which is claimed to be the Shaffie school. ${ }^{61}$ Except for the basic pillars of the faith and some limited issues regarding primary sources of Islamic law (the Quran and Sunna), there are different opinions among Islamic jurists thereby allowing the flexible application of Islamic law. The judges may be from different schools of thought and this may lead to inconsistency in decisions in cases involving similar issues and material facts.

This occurs especially on matters that involve the application of the secondary sources of Islamic Law (the scholastic consensus and analogy), which depend much upon the school of thought to which the judge belongs. Lack of codified and uniform Islamic substantive law to be applied by the sharia courts has thus created the likelihood of decisions to be inconsistent. The absence of codified rules means that there are no guiding rules for settlement of disputes submitted to sharia courts on different matters that come under their jurisdiction. It is to be noted that the presence of a codified sharia law does not eliminate the inconsistency in interpretation, but may mitigate the problem.

\subsection{Secularism}

Secularism is one of the basic principles of the FDRE Constitution and, in effect, the state and religion are separate - with each not allowed to interfere in the affairs of the other. ${ }^{62}$ However, sharia courts are set up, staffed and funded by the government although they are not part of the regular court structure. One could challenge the propriety of sharia courts on grounds of secularism, and may object the role of the government in establishing sharia courts and its act of providing them with budget.

In principle, it is a legitimate concern to invoke secularism to challenge the establishment and operation of sharia courts. However, the interest of the sizeable Muslim population in Ethiopia seems to justify the exception to

${ }^{61}$ Zaki Mustapha, supra note 10 , at 143 . Although they do not identify themselves as such, one can also find Shia Muslims in Ethiopia in different parts of the country as manifested by their practice of the religion.

${ }^{62}$ See Article 11 of the FDRE Constitution. 
secularism in relation to the jurisdiction of sharia courts. In other words, secularism is compromised in the interest of religious diversity permitting parties to choose the forum of adjudication in personal matters. To this end, the FDRE Constitution embodies a provision that guarantees parties to have choice of forum without, however, being subjected to the compulsory jurisdiction of the sharia courts. ${ }^{63}$ This is in concordance with the legal pluralism recognized under the Constitution according to which a compromise is made to the notion of secularism in favour of the settlement of personal and family matters by religious and customary systems.

\section{The Sharia Courts, the Supreme Court and the House of Federation}

The Federal Supreme Court has an extraordinary power of review of any court's final decision through its cassation power as indicated under the FDRE Constitution and the Federal Courts Proclamation. Whether or not final decisions made by sharia courts fall within the cassation power of the Federal Supreme Court is examined on the basis of the Kedija Beshir's case and the relevant laws.

The Kedija Beshir case shows that if a sharia court proceeds to see and makes final determination on a case, the decision can be reviewed by both the Federal Supreme Court and the House of Federation. However, if one reads the provision of the Sharia Proclamation, a case filed to sharia courts may not be reviewed by ordinary courts and vice versa and this rule seems to bar the possibility of review of decisions of sharia courts by ordinary federal courts in general including the Federal Supreme Court.

The Cassation Division of the Federal Supreme Court reviewed the Kedija Beshir case on the basis of Article 80(3)(a) of the FDRE Constitution and Article 10 of the Federal Courts Proclamation. The issue that arises at this juncture is whether Article 80(3) of the Constitution is relevant to justify the cassation jurisdiction of the Federal Supreme Court to review final decisions of sharia courts even upon the failure of the latter courts to secure the express consent of the parties.

As stipulated under Article 80(3)(a) of the FDRE Constitution: "The Federal Supreme Court has a power of cassation over any final court decision containing a basic error of law. Particulars shall be determined by law". The phrase "any final court decision' under Article 80(3) may not be construed to include decisions of sharia courts. This is because the scope of Article 80(3) is limited to the final decisions of regular courts, be it federal or regional courts, and does not

${ }^{63}$ Majamba, supra note 42, p. 18. 
seem to extend to sharia courts as the preceding and subsequent sub-articles of Article 80 of the Constitution refer only to the regular courts of the land. ${ }^{64}$

This interpretation is substantiated by Article 10 of the Federal Courts Proclamation that specifies the types of final decision of regular courts that qualify for review by the Cassation Division of the Federal Supreme Court. The provision makes express reference only to regular courts and does not cover final decisions delivered by sharia courts. ${ }^{65}$ Moreover, the list of cases stated

${ }^{64}$ Article 80 of the Constitution:

\section{Concurrent Jurisdiction of Courts}

1. The Federal Supreme Court shall have the highest and final judicial power over Federal matters.

2. State Supreme Courts shall have the highest and final judicial power over State matters. They shall also exercise the jurisdiction of the Federal High Court.

3. Notwithstanding the Provisions of sub-Articles 1 and 2 of this Article;

(a) The Federal Supreme Court has a power of cassation over any final court decision containing a basic error of law. Particulars shall be determined by law.

(b) The State Supreme Court has power of causation over any final court decision on State matters which contains a basic error of law. Particulars shall be determined by law.

4. State High Courts shall, in addition to State jurisdiction, exercise the jurisdiction of the Federal First-Instance Court.

5. Decisions rendered by a State High Court exercising the jurisdiction of the Federal First-Instance Court are appealable to the State Supreme Court.

6. Decisions rendered by a State Supreme Court on Federal matters are appealable to the Federal Supreme Court).

It is to be noted that many proclamations stipulate that decisions of different tribunals are subject to review by regular courts. For instance, almost all proclamations establishing administrative tribunals such as the ones dealing with tax, labour civil service, and pension matters incorporate provisions stipulating that final decisions of such tribunals on questions of law are subject to review by courts of the law and in most cases the review is made by the Federal High Court and in a limited case by the Supreme Court as in the case of Civil Service Appeal Tribunal. Once decisions of administrative tribunals appear before regular courts, they fall under Article 10 of the Federal Courts Proclamation and Article 80(3) of the Constitution and one could still say it is cassation review of final decisions of regular courts. Such scheme is not indicated when it comes to the sharia courts.

65 The Federal Courts Proclamation No. 25/96 provides that the Federal Supreme Court has a final judicial power over federal matters. The final decision subject to cassation review by the Cassation Division of the Federal Supreme Court include final decisions of the Federal High Court rendered in its appellate jurisdiction, final decisions of the regular division of the Federal Supreme Court, and final decisions of the Regional Supreme Courts rendered as a regular division or in its appellate jurisdiction. See Article 10 of the Federal Courts Proclamation. 
under the Federal Courts Proclamation that qualify for cassation review refers only to regular courts. The list embodied in the Federal Courts Proclamation thus confirms the interpretation that the scope of Article 80(3) of the Constitution does not include the final decisions of the sharia courts. In short, the Federal courts, including the Federal Supreme Court, do not have jurisdiction to review decisions rendered by sharia courts since the interpretation of the relevant provisions of the law does not confer such power on them.

The House of Federation, as an organ entrusted with the authoritative power of interpretation of the Constitution, was involved in the Kedija Beshir case. The case culminated with the decision of the HoF which declared the final decision of the Sharia Courts unconstitutional on the ground that there was no prior consent of one of the parties to the case. The review made by the HoF can be justified on the basis of the constitutional provisions that mandate the House to make the final authoritative decision on all constitutional disputes and by virtue of the proclamations relating to the power of the House and its subsidiary organ, the Council of Constitutional Inquiry.

The Council has the power to investigate complaints which claim that a certain law or a decision of state organ contravenes the Constitution. ${ }^{66}$ The word 'state organ' includes organs with judicial function, and this seems to extend to sharia courts as they have such power. ${ }^{67}$ It then makes recommendation to the House of Federation on a decision to be adopted by the House regarding a complaint that gives rise to constitutional interpretation. The Federal Courts Proclamation states that a question of the constitutionality of final decision made by the sharia courts falls within the competence of the Council of Constitutional Inquiry and the HoF. But, there is a limit to the power of the House of Federation to hear and make decisions on final judgments delivered by sharia courts. As will be discussed in the next section, the review made by the House is confined to procedural questions and not in relation to substantive final decisions of sharia courts. However, there is no case-law that supports this contention and the reasoning is based entirely on the arguments invoked on the basis of analysis of the provisions of the relevant laws and literature.

\section{Legal Pluralism, Sharia Courts and Constitutional Issues}

Legal pluralism is capable of different connotations, depending on the context in which it is employed. It mainly refers to the incorporation or recognition of customary norms or institutions within state law or to the independent co-

\footnotetext{
${ }^{66}$ See Article 17(2) of Council of Constitutional Inquiry Proclamation.

${ }^{67}$ Ibid, Article 2(6).
} 
existence of indigenous norms and institutions alongside state law. ${ }^{68}$ Legal pluralism makes it inevitable that there are multiplicities of legal orders that are diverse, uncoordinated, co-existing or overlapping bodies of law. ${ }^{69}$ The diverse sources of normative ordering include official legal system, and customary, religious, functional and community systems. ${ }^{70}$ These different norms apply to different persons in the same situation. ${ }^{71}$ Thus in a heterogeneous society, the recognition accorded to legal pluralism realizes multicultural accommodation. This is why states try to facilitate practices and norms, for example, by exempting group members from certain laws, or by awarding identity groups some degree of self-rule. ${ }^{72}$ If the state grants various religious or and cultural groups self-governance over areas like family law (marriage and divorce), this increases the autonomy that these communities enjoy. ${ }^{73}$

Legal pluralism and the resultant recognition of non-state laws are advantageous because they are said to be 'closer' geographically and culturally, more accessible and flexible, well-suited to address deep conflicts, relatively inexpensive. The overall burden of engaging with them is also considerably less than in the case of the state's legal system. ${ }^{74}$ One of the demerits of legal pluralism is that it is not sensitive to human rights of individuals. Moreover, its downsides include non-conformity (or even difference) which may involve discrimination, and the potential for the emergence of competing clams of authority; and the imposition of conflicting demands of norms. ${ }^{75}$

The diverse sources of normative ordering under legal pluralism can clash with each other and state laws, particularly when their underlining norms and processes are inconsistent, and such clashes are the most dynamic aspects of legal pluralism. ${ }^{76}$ This is best depicted in what Shachar called 'the paradox of

${ }^{68}$ Brian Tamanaha (2007), "Understanding Legal Pluralism: Past to Present, Local to Global”, Sydney Law Review, Vol. 30, p. 390.

${ }_{70}^{69}$ Ibid, 375.

70 Ibid, 397; see also International Council on Human Rights Policy (2008), "An Approach Paper: Research Project on Plural Legal Orders and Human Rights”, p. 4

${ }^{71}$ Grant R. Woodman (1996), "Legal Pluralism and the Search for Justice", Journal of African Law, Vol. 40, p. 160.

72 Ayelet Shachar (1998), 'Group Identity and Women's Rights in Family Law: The Perils of Multicultural Accommodation', The Journal of Political Philosophy, Vol. 6, No. 3, p. 286.

${ }^{73}$ Ibid, p. 289.

${ }_{75}^{74}$ International Council on Human Rights Policy, supra note 70, p. 5.

${ }^{75}$ Ibid, see also Tamanaha, supra note 68, p. 375

${ }^{76}$ Ibid, p. 400 
multicultural vulnerability'. ${ }^{77}$ There are different schemes adopted by states to deal with such discords through, for instance, provisions like conflict rules, and choice of law rules. ${ }^{78}$ Some of the specific provisions to manage the conflicts among different normative ordering include the following:

a) One common arrangement is for the state legal system to assume a position of neutrality with respect to the various communities and religions, allowing a degree of autonomy to each. ${ }^{79}$ For example, there can be an exemption from compliance to state law such as the clauses in Zambia's and Zimbabwe's constitutions, which exempt customary norms from compliance with the constitutional standard. ${ }^{80}$

b) Another mechanism is for state law to absorb competing systems. A common mechanism is to explicitly recognize customary, religious, economic, or community norms, or to explicitly recognize and lend them some support (which may be financial or enforcement). ${ }^{81}$ To this end, the state may, as in the cases of India, Pakistan or Niger opt to recognize or even create institutions outside the formal state legal system to mediate and resolve disputes. ${ }^{82}$ In other words, the state legal system recognizes the validity of private arbitration decisions, or even encourages parties to have recourse to such arbitration. ${ }^{83}$ The state may also allow the application of different normative ordering by limiting its scope. For instance, the legal regimes in Israel, Malaysia, and Indonesia permit the application of different laws, especially those affecting personal status (such as marriage, adoption, and divorce) to different people depending on their religious identity, or, legal regimes may allow indigenous people to be subject to their own customary rules as in USA and Canada. ${ }^{84}$

c) The other means is for the state official system to recognize the special status of customary systems but only in so far as they are not contrary to constitutional standards, as in South Africa. ${ }^{85}$

77 Shachar, supra note 72 , p. 289 . The paradox of multicultural vulnerability is the phrase used to indicate the possible clash between the recognition given to cultural and religious groups' autonomy over family matters on the one hand and the individual rights of vulnerable groups such as women, minority, and children in the society, on the other. See Shachar, p. 289-290).

${ }^{78} \mathrm{Ibid}$, at 400, and 403-407.

${ }^{79}$ Ibid.

${ }^{80}$ International Council on Human Rights Policy, supra note 70, p. 6.

${ }^{81}$ Tamanaha, supra note 68, p. 404.

${ }^{82}$ International Council on Human Rights Policy, supra note 70, p. 6.

${ }^{83}$ Tamanaha, supra note 68, p. 404.

${ }^{84}$ International Council on Human Rights Policy, supra note 70, at 6.

${ }^{85}$ Ibid. 
d) Another option available is for state law to make aggressive efforts to subjugate the different normative systems that are in conflict with state law by declaring them illegal and trying to eliminate them. ${ }^{86}$ This constitutes part of an 'abolitionist approach' and, in relation to certain issues, it resonates the feminist stance that calls for the elimination of customary practices that contradict human rights. ${ }^{87}$ This approach rejects religious and cultural norms as mere sources of oppression of and discrimination against women. ${ }^{88}$

In light of the above courses of action, let us see how the FDRE Constitution deals with legal pluralism and the relationship between different normative ordering (including the law relating to the Sharia Courts) and the concern for human rights issues.

One of the challenges that legal pluralism poses to human rights relates to the uniform application of human rights in Ethiopia as envisaged under the Constitution. There is a tension between legal pluralism (which is in favour of particularity in application) and the human rights instruments adopted by Ethiopia and enshrined under the Constitution (which are universal in nature and require uniform application). Different normative ordering recognized under the Constitution could, therefore, constrain the uniform application of human rights enshrined under the Constitution as their underpinning norms and processes are obviously bound to differ in many instances. This is most visible with respect to the constitutional guarantee of the rights of women in general and gender equality in particular vis-à-vis the treatment of women in the customary and religious laws and systems.

Sharia courts apply substantive sharia law that has different perceptions and approaches to issues of gender equality. There are different ways of treating women in Islamic law that are to be applied by the sharia courts in such areas like divorce, partition of property, and inheritance. ${ }^{89}$ How can one reconcile

${ }^{86}$ Tamanaha, supra note 68 , p. 404

${ }^{87}$ Celestine I. Nyamu (2000), "How Should Human Rights and Development Respond to Cultural Legitimization of Gender Hierarchy in Developing Countries?", Harvard International Law journal, Vol. 41, p. 392.

88 Ibid; See also Rhoda Howard Hassman (2002), "Duelling Fates: Should the International Legal Regime Accept a Collective or Individual Paradigm to Protect Women's Rights?", Michigan Journal of International Law, Vol. 24, Pp. 381-382.

${ }^{89}$ Islamic law applies different rules regarding inheritance, divorce, partition of property upon divorce on the basis of sex and offers rich explanations for doing so. For instance, a woman is entitled to half a share of a man in inheritance; a husband may divorce his wife through a unilateral pronunciation of divorce but the same right is not given to a wife. For the Status of women in Islam and their differential treatment 
such variation in the treatment of women depending upon on the type of the law applied by the Sharia Courts, and how can these be reconciled with issues such as the principles of gender equality and non-discrimination enshrined under the Constitution? Which mechanism is used by the Ethiopian Constitution when the decisions rendered by sharia courts are alleged to be against the provisions of the Constitution or its human rights norms? Should decisions of the sharia courts be in compliance with the Constitutional standard? In other words, does the supremacy clause under Article 9 of the FDRE Constitution apply to decisions of sharia courts that are alleged to contravene the Constitutional standard set by Article 9? Do the human rights provisions that are enshrined under the Constitution override judgments of sharia courts that are found to be against these human rights norms? Can the House of Federation as an authoritative interpreter of the Constitution review final substantive decisions of sharia courts and declare them unconstitutional if they are found to be incompatible with the provisions of the Constitution?

Unlike the constitutions of some countries (such as Kenya), the Ethiopian Constitution has not crafted an explicit rule designed to contain the potential conflict between state laws and the various normative ordering that it recognizes. Besides, there is no case-law regarding this question that could clarify the problem. However, on the basis of the analysis of various legal provisions, two broad strands of opposing arguments can be developed. One line of argument is in favour of the assertion that final decisions of the sharia courts should be compatible with the supremacy clause of the Constitution and human rights norms enshrined under the Constitution, and human rights treaties ratified by the country. ${ }^{90}$ One can also contend that final decisions of the Sharia Courts are not necessarily expected to be in line with the norms of the Constitution. According to this course of argument, the decisions of sharia courts should rather be treated as exception to the supremacy clause and human rights norms.

Arguments in support of the first line of argument can be found in the provisions of the Constitution itself and the legislations that regulate the power

and its justification, see Jemal Badawi (1971), "The Status of Woman in Islam", Allttihad, Vol. 8, No. 2; Yusuf Al Qaradawi (2002), The Status of Women in Islam; see also, Hammudah Abd' Al Lati (1998), Islam in Focus, $3^{\text {rd }}$ ed.

${ }^{90}$ Getachew Assefa indirectly holds this view on the basis of his brief comment on the Kedija Beshir Case. He seems to suggest that the decisions of sharia courts have to be in line with the fundamental rights and freedoms and his suggestion is based on the mere involvement of the Supreme Court and the House of Federation in the case. See Getachew Assefa (2008), "Assessment of Ethiopian Courts", in National Judicial Institute, Independence, Transparency and Accountability in the Judiciary of Ethiopia, A research Report, commissioned by the Canadian International Development Agency, p. 110. 
of the House of Federation. The Constitution contains a supremacy clause that provides that any law, decision of state organ or official and customary practices that are contrary to the spirit of the Constitution shall be of no effect. The phrase 'any decision of state organ' can be constructed to include any decision made by the executive, legislature, judiciary, or any organ with judicial power. This includes, therefore, decisions rendered by sharia courts. Hence if decisions of the sharia courts are alleged to be in transgression of the constitutional provisions, they shall be of no effect. This means that any final decision of sharia courts should be compatible with the supremacy clause of the Constitution and other provisions of the Constitution relating to fundamental rights, including the rights of women.

This line of argument is, in the final analysis, pursues the abolitionist approach. In the end, it essentially means the substitution of religious and customary norms by the state laws. It does not take note of the religious and cultural concerns and sensitivities involved in family matters subject to the jurisdiction of religious and cultural systems. This is because it ignores the values and essence of religious and customary norms as being a source of cultural attributes and social cohesion in the lives of many women. ${ }^{91}$ In customary and religious matters, women who assert their interests may not necessarily identify themselves as women, but rather in terms of other affiliations such as religion, culture, and ethnicity. ${ }^{92}$ This is the case in Ethiopia, particularly in areas where Islam has a stronghold, such as the Somali, Afar, Hararri, and East and South East part of Oromia Regional States. As a result, in the event of conflict between matters governed by religious and customary laws on the one hand and state laws on the other, one needs to give due regard to customary and religious concerns. Uncompromising antagonism towards religion can indeed be counter-productive. In effect, it forces women in the religious or cultural communities to choose between individual rights vis-a-vis spiritual or social cohesion, and they usually prefer the latter. ${ }^{93}$

The arguments against the first perspective are also based on the Constitution which expressly grants constitutional recognition and status to the settlement of disputes related to personal matters by customary and religious bodies so long as parties refer a matter to such institution though their own consent. This implies that the Constitution acknowledges the difference in the norms and processes

${ }^{91}$ See Cheryl B. Preston (2003), "Women in Traditional Religions: Refusing to Let Patriarchy (or Feminism) Separate Us from the Source of Our Liberation", Mississippi College Law Review, Vol. 22, Pp. 199-200; see also Rhoda HowardHasman, supra note 88, Pp. 381-382.

${ }^{92}$ Rhoda Howard-Hasman, Ibid.

${ }^{93}$ Preston, supra note 91, p. 199-200; see also Rhoda Howard-Hassman, Ibid., p. 386. 
between state law and customary and religious laws; and also tolerates their final decision in matters affecting personal status of individuals when the parties thereof voluntarily submit their cases to such organs. This argument is reinforced by the arrangement under the 1999 Sharia Courts Establishment Proclamation. As stated earlier, Article 5(4) of this Proclamation provides that once a case is submitted to sharia courts after meeting all procedural requirements, it shall not be taken to the regular courts and vice versa.

According to the second line of argument, this arrangement is made to draw a parallel structure between the two different court systems and thereby maintain the non-reviewability of decisions of one by the other. Hence, it can be argued that the supremacy clause under Article 9(1) of the Constitution does not apply to decisions of sharia courts even if the substantive decisions made by sharia courts are discriminatory in nature or in conflict with human right issues under the Constitution. This interpretation leads to the conclusion that decisions of sharia courts that may even breach constitutional norms can be treated an exception to Article 9(1).

Unlike Zambia and Zimbabwe, the Ethiopian Constitution fails to explicitly articulate this exception. Yet, personal matters settled by religious and customary institutions need to be exempted from compliance with the standard stipulated under Article 9(1) of the Constitution. Reviewing such decisions and declaring them unconstitutional is inconsistent with the role of sharia courts in adjudicating personal and family matters that are important to Muslims and that are also the manifestation of their identity. Such review also implies the imposition of uniform laws on Muslims regarding matters that are intrinsically associated with them.

The Ethiopian legal regime pursues a compromise formula because it gives Muslims the right to consent to or reject the jurisdiction of the court, and at the same time avoids the uniform application of civil laws to Muslims who constitute a significant segment of the Ethiopian population. ${ }^{94}$ The pre-condition of consent of both parties on the exercise of jurisdiction by sharia courts protects

${ }^{94}$ Currently, Muslims are found in all parts of Ethiopia. They have a stronghold in some part, especially in Somali, Afar, Harrari Regional States and some Zones in Oromia (Bale, Arsi, East and West Harrarghe and Jimma) and in Silte Zone in South Nation, Nationalities and Peoples' Regional State. As per the Housing and Population Census of 2007, Muslims account for $33.9 \%$ of the population. See the Federal Democratic Republic of Ethiopia Population Census Commission (2008), "Summary and Statistical Report of the 2007 Population and Housing Census: Population Size by Age and Sex", p. 18. A large number of cases concerning personal matters among Muslims end up before sharia courts, especially in area such as Afar, Somali and Harrari Regional States. 
the rights of Muslims who do not want to be adjudicated by these courts. And on the other hand, personal law to be enforced by the sharia courts may be exempted from the uniform application of civil law for those who consent to the jurisdiction of sharia courts. ${ }^{95}$ So, if parties to a dispute voluntarily take their case to a sharia court, the outcome should be exempted from constitutional standards. Furthermore, subjecting final decision of sharia courts to the supremacy clause and the human rights norms of the constitution goes against the very essence of legal pluralism advocated by the Constitution. Thus, final decisions made by sharia courts on matters within their remit have to be considered in the context of legal pluralism and be treated as a compromise to the constitutional standard set under Article 9(1).

However, the House of Federation is entitled to review final decisions made by sharia courts. But, for the aforementioned reasons, the scope of its power is limited to procedural questions such as failure to comply with express consent, or where sharia courts exceed the mandate granted to them under Articles 34 and 78 of the Constitution. Thus the authority of the House of Federation to review and examine the constitutionality of the outcome of final decisions of sharia courts should be limited even if the decisions may be inconsistent with a provision embodied in the Constitution.

If final decisions rendered by the sharia courts are reviewed by the House of Federation and finally declared unconstitutional, this may be treated by Muslim communities as an onslaught on their religious values and identity. This may trigger a counter-measure towards a stricter interpretation and practices. In the words of Shachar, such measure is called a 'reactive culturalism'. It arises from a reaction of identity group's active resistance to external forces of change and entails a strict adherence to the group's traditional laws, norms and practices. ${ }^{96}$ A well-intentioned attempt to protect the rights of women may thus be perceived by religious and identity groups as an external pressure or threat to its values and identity and may then lead to a firm assertion of and obedience to their faith and values and even put women in a strict cultural, social and legal position.

95 Article 74 of the Revised Family Code provides that effects of marital ties are regulated by the Code whether a marriage is concluded as per civil, customary or religious system. However, as discussed earlier, marriage concluded according to Islamic law is exempt from the application of this rule so long as the parties thereof consent to settle their case by the application of Islamic law. This does not mean that the effect of marriage concluded according to Islamic rule is governed by Islamic law automatically. The Islamic law applies only when a dispute arises and the parties opt for the Sharia Courts.

96 Ayelet Shachar (2001), Multicultural Jurisdictions: Cultural Differences and Women's Rights, Cambridge University Press, p. 35. 
The reaction of Indian Muslims to a decision of the Supreme Court of the country in one case enlightens the reaction of the Muslim community to what they perceived was an external threat to their identity and its consequences to the rights of women. The ruling of the Supreme Court of India in 1985 in a case that involved family matters generated fury and propelled a vigorous campaign by Muslims on the ground that the decision would impose the values of the majority Hindus on the minority Indian Muslims. The protests culminated in the enactment of legislation by parliament that exempted Muslim women from state laws on personal matters related to divorce thereby eliminating the protection they had under the state law. ${ }^{97}$ A genuine restructuring of the differential treatment of women in religious and customary systems should not, therefore, be imposed on the system. As underscored by Shachar, the presence of state jurisdiction as a competitive optional forum in itself creates a spur for the religious and customary systems to react to the needs of the vulnerable groups or else risk losing members dissatisfied with the system. ${ }^{98}$

${ }^{97}$ The case was between Mohammed Ahmed Khan v. Shah BanoBegum, decided on by the Indian Supreme Court in 1985. The facts of the case, taken from Shachar's work, are the following: A Muslim woman, Shah Bano, was divorced by her husband, Mohammed Ahmed Khan, of more than forty years by way of a unilateral (talaq) divorce following a three year separation. Shah Bano lodged a case to the lower courts seeking maintenance payments from her ex-husband. The case finally reached the Supreme Court of India, which delivered a decision in her favour. The decision of the Supreme Court that was in favour of Shah Bano was perceived by the representatives of the Muslim minority community as attestation of attempts by the Hindu majority to undermine the identity of the minority Muslims. In response to the decision, Muslim religious leaders embarked on a massive political campaign in which they demanded that the government to "exempt" Muslim women from resorting to state law in determining the pecuniary effects of a religious divorce, thus depriving them of rights and remedies available to fellow Indian female citizens. The Indian Parliament conceded to the pressures of the campaigns of Muslims. It overruled the Court's decision in Shah Bano by promulgating an Act that protects the rights of Muslim women upon divorce. The legislation stripped off the rights of Muslim women to appeal to state courts for post-divorce maintenance payments. In addition, it relieved Indian Muslim ex-husbands from other post-divorce obligations toward their children. As a result, the legislation deprives Indian Muslim women of the benefits that they would receive if they lived in Egypt, as well as many other Muslim countries where Sharia family law codes are applied through state courts. For the facts of the case and its effects on the rights of Muslim women, see Ayelet Shachar, Religion (2005), "State, and the Problem of Gender: New Modes of Citizenship and Governance in Diverse Societies", McGill Law Journal, Vol. 50, No. 1, p. 68.

${ }^{98}$ Shachar, supra note 96, pp. $140-141$. 
In short, the second line of argument appears to be sound by virtue of the schemes of legal pluralism adopted by the Constitution and the 1999 Sharia Courts Proclamation. The other abolitionist option thus violates legal pluralism to the detriment of sensitive concerns in religious and customary practices and norms related to family matters.

\section{Implication to International Human Rights Obligations}

The argument that final decisions of Sharia Courts have to be treated as exception to the constitutional standards has an implication to international human rights instruments ratified by Ethiopia. It triggers questions about Ethiopia's commitment under various human rights instruments ratified by the country that contain provisions prohibiting discrimination against women. ${ }^{99}$ Personal status laws in Ethiopia, which could also fall within the jurisdiction of sharia courts, are often considered the area of the law in which discrimination is entrenched on the ground of gender. ${ }^{100}$ That is why a state party to, for instance, the $C E D A W$ is obliged to fight cultural practices that discriminate women. To this end, a state party is under obligation to undertake appropriate measures in order to eliminate discrimination against women in all matters relating marriage and family relations. ${ }^{101}$

The constitutional provisions that give recognition to customary and religious institutions in the settlement of personal disputes (subject to the consent of parties) may not be in conformity with the provisions of these international human rights instruments. This in turn triggers issues related to the status of international human rights under the Federal constitution, which in itself is a subject of debate in Ethiopia and in itself can become a separate topic for

${ }^{99}$ Ethiopia has become a party to the CEDAW in 1981. It signed it on 8 July 1980 and ratified it on 10 September 1981.

$<$ http://treaties.un.org/Pages/ViewDetails.aspx?src=TREATY\&mtdsg_no=IV-

$8 \&$ chapter $=4 \&$ lang $=$ en $>($ Accessed on 11 June 2011). The reservation Ethiopia made to the Convention upon the ratification is on paragraph 1 of Article 29 of the

Convention and the then government expressed that it would not be bound by the stated paragraph. See Convention on the Elimination of All Forms of Discrimination against Women: Declarations, reservations, objections and notifications of withdrawal of reservations relating to the Convention on the Elimination of All Forms of Discrimination against Women, UN, CEDAW/SP/2006/2,Geneva, 2006; See <http://daccess-dds-ny.un.org/doc/UNDOC/GEN/N06/309/97/PDF/N0630997.pdf?OpenElement> (Accessed on 11 June 2011).

100 Jasmine Mousa (2005), The Reform of Sharia-derived Divorce Legislation in Egypt: International Standards and the Culture Debate, p. 1.

101 See Article 16 of the 1979 Convention on the Elimination of All Discrimination against Women. 
discussion. ${ }^{102}$ What appears to be impliedly evident from the interpretation of the Constitution is that the particularity of application of some human rights issues as related to personal matters are given preference over universal application of human rights as well as national laws. This is done with the objective of accommodating, to some extent, religious and customary rules governing personal status when parties mutually choose such rules in the settlement of their disputes.

\section{Concluding Remarks}

The sharia courts have not been performing well with respect to the rights and concerns of women. ${ }^{103}$ It has been alleged that women would not tend to prefer them for resolution of family and personal disputes as a result of the differential treatment of women in Islamic law. ${ }^{104}$ However, the problem is usually attributable to the prejudices of judges in sharia courts towards the position and status of women in the customary norms of the society. ${ }^{105}$ In the Ethiopian context, the application of sharia law is influenced by the customary rules of a region or a dominant ethnic group, which in many instances are not in tune with

${ }^{102}$ See the following literature in relation to the status of international human rights treaties in Ethiopia: Rakeb Messele (2003), "Enforcement of Human Rights in Ethiopia", Research Report, APAP (Addis Ababa), Gebreamlak Gebregiorgis (2008), "The Incorporation and Status of International Human Rights under the FDRE Constitution", in Girmachew Alemu and Sisay Alemahu, eds., "The Constitutional Protection of Human Rights in Ethiopia: Challenges and Prospects', Ethiopian Human Rights Law Series, Vol. 2, Faculty of Law, AAU; Sisay Alemahu (2008), 'The Justiciability of Human Rights in the Federal Democratic Republic of Ethiopia', African Human Rights Law Journal, Vol. 8; Chi Mgbako, et al (2008), "Silencing the Ethiopian Courts: Non-Judicial Constitutional Review and its Impact on Human Rights", Fordham International Law Journal, Vol. 15, No. 1; Takele Seboka (2009), "The Monist-Dualist Divide and the Supremacy Clause: Revisiting the Status of Human Rights Treaties in Ethiopia", Journal of Ethiopian Law, Vol. 23, No. 1; Mohammed Abdo (2011), "The Status and Enforcement of Social and Economic Rights under the FDRE Constitution", Vol. 24, Journal of Ethiopian Law.

103 Communiqué of Addis Ababa Muslim Women's Council (2003), at 1.

104 Original Woldegioris (2002), "Democratization Process and Gender", in Bahru Zewde and Siegfried Pausewang, Ethiopia: The Challenge of Democracy from Below, Elanders Gotab ( Sweden), p. 175.

${ }^{105}$ It does not mean that Islamic law does not have rules contradictory to human rights norms. The sharia law enforced by sharia courts make a different treatment on the basis of gender as mentioned earlier. Of course, there are ample justifications for preferential treatment on the basis of gender in Islamic law. For details read Jemal Bedawi and Yusuf Al Qaradawi, supra note 89. 
the rights of women. ${ }^{106}$ This may have a role in shaping the mindsets and views of judges in matters involving women.

The jurisdiction granted to sharia courts raises questions and concerns about human rights provisions enshrined under the FDRE Constitution regarding gender equality and protection against discrimination. However, the Constitution has not provided a specific mechanism as to how decisions of sharia courts that are in conflict with constitutional standards can be dealt with. In other words, the Constitution fails to clearly state whether its supremacy clause and provisions on human rights prevail over final decisions of sharia courts that are in conflict with them.

As indicated in the preceding discussion, the Constitution seems to have recognized the final decisions delivered by sharia courts as exception to its supremacy clause and human rights norms. This seems to have been made mainly in favour of legal pluralism. With regard to the potential for conflict between the decisions of sharia courts and human rights instruments, the legal pluralism enshrined in the Ethiopian Constitution and the 1999 Sharia Courts Proclamation seem to have pursued the notion of 'cultural relativism' in personal matters rather than the universality of human rights. This is because the FDRE Constitution recognizes parallel personal and family laws based ethnoreligious frameworks and such structure has to be maintained if the parties opt for such systems.

The concerns of the 'abolitionist' option can be addressed by raising the awareness of women so that they can make informed decision as to which forum is to their best interest. Such pursuits coupled with the power of the state to encourage and facilitate reforms regarding the treatment of gender issues in the sharia courts as well as customary systems can indeed gradually address the constitutional and human rights concerns discussed in this article.

${ }^{106}$ Ibid. 